\title{
Carcass Traits in Sheep Receiving Acacia mearnsii Condensed Tannin Extract to Control Endoparasites
}

\author{
Helder Louvandini ${ }^{1}$, Franceska Borges $\mathrm{Cenci}^{2}$, Juliano Issakowicz ${ }^{1}$, Ana Claudia Koki Sampaio ${ }^{1}$, Tiago do Prado \\ Paim $^{1}$, Samuel Ciminelli de Araújo ${ }^{2}$, Daniel Martins Costa ${ }^{2}$, Adibe Luiz Abdalla $^{1}$ \& Concepta McManus ${ }^{2}$ \\ ${ }^{1}$ Centro de Energia Nuclear na Agricultura, Universidade de São Paulo, NAPTISA, Piracicaba, SP, Brazil \\ ${ }^{2}$ Faculdade de Agronomia e Medicina Veterinária, Universidade de Brasília, Brasília, Distrito Federal, Brazil \\ Correspondence: Juliano Issakowicz, Centro de Energia Nuclear na Agricultura, Universidade de São Paulo, \\ NAPTISA, Av. Centenário, 303, 13400-970, Piracicaba, SP, Brazil. E-mail: issakowicz@cena.usp.br
}

Received: June 3, 2014 Accepted: July 15, 2014 Online Published: September 15, 2014

doi:10.5539/jas.v6n10p128 URL: http://dx.doi.org/10.5539/jas.v6n10p128

\begin{abstract}
We evaluated carcass traits from twenty 6-month-old Santa Ines lambs under tropical grazing (Andropogon gayanus) receiving condensed tannin from Acacia mearnsii once a week for 13 weeks to control endoparasites. Ten animals were treated with tannin (TG) and the remainder (10 animals) received a diet without tannin (CG). At slaughter, the following measurements were taken: live weight, carcass weight, half-carcass weight, carcass length, fat cover, skin weight and thickness, weight of thoracic and abdominal organs, scrotum and commercial cuts. The $12^{\text {th }}$ rib was removed for determination of muscle, fat and bone percentages, as well as their chemical analysis. Skin thickness was greater and commercial cuts (loin and rib/belly) were lower in TG. Animals that received tannin had a lower percentage of ether extract and higher protein in the $12^{\text {th }}$ rib. Condensed tannin from Acacia mearnsii did not impair carcass trait quality but decreased ether extract and increased protein content.
\end{abstract}

Keywords: food safety, lipids, meat quality, nutrition, protein

\section{Introduction}

Consumer markets require high quality lamb, mainly in terms of nutritional composition. Gastrointestinal parasites in sheep generally lead to lower weight gain and consequently a low carcass yield. Moreover, they can provoke animal death and are related to economic losses for farmers. Therefore, the utilization of anthelminthic drugs is necessary, but their residues can reduce meat quality for the consumer (Rahmann \& Seip, 2006).

Alternative measures of control are sought to minimize anthelminthic chemical use and proportionate higher food safety (Rahmann \& Seip, 2006). These can also turn the production systems more sustainable and environmentally friendly.

Some plants rich in phenolic compounds such as tannins have antihelminthic properties that have been successfully utilized for gastrointestinal nematode control (Cenci et al., 2007), although their effects on performance and carcass quality are poorly studied. Tannins may improve myoglobin stability due to lower oxidation to meta-myoglobin, which results in better coloured meat, leading to longer storage time and quality maintenance under exposure to oxygen (Luciano et al., 2011). They also promote a fresher looking meat, which provides more appeal to the consumer.

Tannin-rich diets also may be useful to improve healthy meat properties in terms of better fatty acid composition. According to Vasta et al. (2009), they may reduce ruminal hydrogenation, increase polyunsaturated and decrease saturated fatty acids. Another important feature is that tannins can complex with proteins (Priolo et al., 2000), decreasing their ruminal degradability and consequently increasing protein output to the intestine.

On the other hand, with prolonged ingestion of these compounds, negative effects on animal performance are often observed. These include reduction in voluntary feed intake due to astringency through tannin-salivary protein complex formation in the mouth, and reduced digestion or metabolic utilization of products (Miller et al., 1995; DeMello \& Devendra, 1995), caused by inhibition of gut enzyme activity and reduction of gut permeability (Walton et al., 2001). Tannins are thus an alternative to reduce drug residues and improve chemical properties of meat. Therefore, the evaluation of quantitative and qualitative carcass traits from animals receiving condensed tannins is a useful tool for providing a better understanding on the effects of tannin on animal 
performance.

This study was carried out to evaluate the carcass traits from lambs that received condensed tannin from Acacia mearnsii to control the endoparasites.

\section{Method}

This study was conducted in the Sheep Management Center of Água Limpa farm of Universidade de Brasília situated at $15^{\circ} 47^{\prime} \mathrm{S}$ e $47^{\circ} 56^{\prime} \mathrm{W}$ Gr., in the Federal District, Brazil.

Twenty entire male 6-month-old Santa Inês lambs were used. They were randomly divided between two treatments: tannin group (TG) with initial body weight of $24.6 \mathrm{~kg} \pm 1.6 \mathrm{~kg}$ and control group (CG) with initial body weight of $23.5 \mathrm{~kg} \pm 0.8 \mathrm{~kg}$, with ten animals in each treatment. The TG received, orally, $18 \mathrm{~g}$ of Acacia negra (Acacia mearnsii) powder dissolved in water once a week for 13 weeks. The tannin source was the pure extract commercially available for the industry: tannery and manufacturing companies. This powder contained $18 \%$ condensed tannin (CT) that was measured using HCL-butanol methods (Makkar, 2003). CG received the same management and diet only, without the powder. This protocol (amount and frequency of tannin) was elaborated so that protein absorption was not affected.

Animals were kept on Andropogon gayanus pasture at a stocking rate of five animals per hectare and supplemented with mineral salt ad libitum. The grass was sampled monthly using random cuts simulating grazing habits of animals. Chemical analyses were carried out to determine dry matter (DM), crude protein (CP), ether extract (EE) and ash (A) according to Association of Official Agricultural Chemists (AOAC, 1995) as well as neutral (NDF) and acid detergent fiber (ADF) according to Van Soest et al. (1991). The mean and standard deviations were $27.7 \pm 0.12 ; 9.4 \pm 2.8 ; 73.5 \pm 3.2 ; 39.5 \pm 2.9 ; 2.6 \pm 0.19$ and $4.86 \pm 0.67$ for DM, CP, NDF, ADF, EE and A, respectively.

Animals were slaughtered through stunning and bleeding after a 12-hour fast. The animal skin was removed, weighed and skin thickness measured using callipers. Thoracic (trachea, lung and heart) and abdominal organs (kidneys and liver) were removed and weighed. Testicles were also weighed.

The carcass was weighed and separated in two half-carcass and the left half-carcass was weighed. Carcass traits were evaluated using procedures adapted from Muller (1987) and Osório et al. (1998). Subcutaneous fat was evaluated subjectively for external distribution, receiving scores of 1 (lean) to 5 (high fat). The carcass length was measured from last cervical vertebra and first caudal vertebra using a metric tape.

Transversal cuts at $11^{\text {th }}$ and $13^{\text {th }}$ rib were performed and the samples stored at $-20^{\circ} \mathrm{C}$. Rib eye area at the $12^{\text {th }}$ rib was measured through drawing the muscle on a transparent grid $\left(1 \mathrm{~cm}^{2} /\right.$ cell) adapted from Cunha et al. (2001). After dissection into muscle, fat and bone according to Cuthbertson et al. (1972), the proportions of each compound were obtained. Tissues were minced together and chemical analyses were carried out obtaining crude protein, ether extract, ash content and dry matter according to Association of Official Analytical Chemists (AOAC, 1995).

Commercial cuts were taken from the right half-carcass adapting the model of Santos et al. (2001), obtaining leg, loin, shoulder, back, rib/belly and neck (Figure 1) and weighed. 


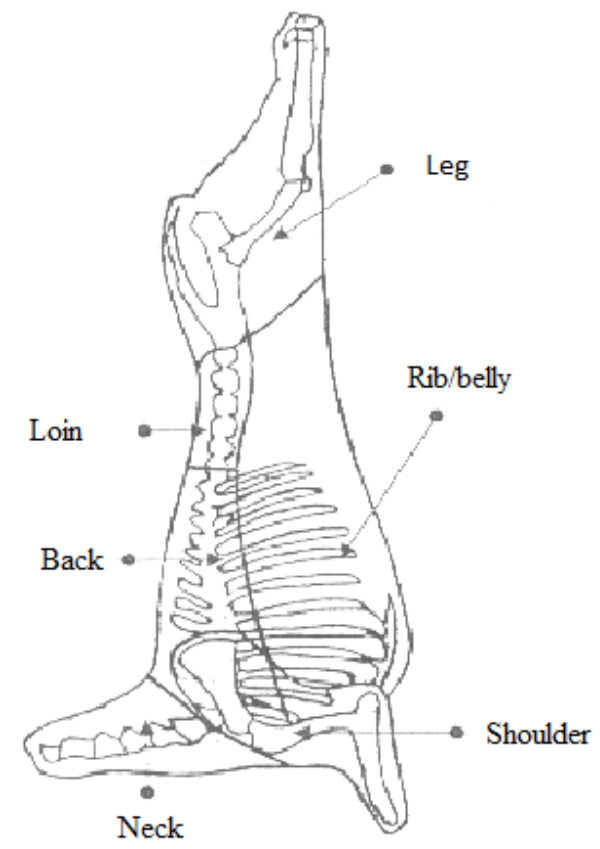

Figure 1. Commercial cuts of sheep half-carcass (adapted from Santos et al., 2001)

Analyses of variance were carried out for all variables. The significant statistical level used was $5 \%$ and SAS v. $9.2 \AA$ (Cary, North Carolina) procedure (PROC GLM) was used.

\section{Results}

The final live weight did not differ $(P>0.05)$ between TG and CG $(25.8 \pm 1.0$ and $25.2 \pm 0.8 \mathrm{Kg}$ respectively).

Carcass weight, half-carcass weight and commercial cut weights did not differ $(P>0.05)$ between groups, except loin and rib/belly (Table 1$)$ where TG showed a lower value $(0.27$ and $0.41 \mathrm{~kg})$ for these cuts respectively compared to the value observed in the carcass of animals in the control group $(0.41$ and $0.49 \mathrm{~kg})$. Similarly the proportion of the loin and rib/belly was lower $(P<0.05)$ in TG $(6.07$ and $9.09 \%)$ compared to CG $(8.95$ and $10.8 \%)$.

Table 1. Least squares means \pm standard error of carcass and commercial cuts weights as well as cuts proportions (on half-carcass weight basis) in santa inês lambs receiving tannin from acacia mearnsii (TG) and a control group not receiving tannin (CG)

\begin{tabular}{llll}
\hline Traits & TG & CG & $P$ \\
\hline Carcass Weight (kg) & $9.5 \pm 0.398$ & $9.2 \pm 0.356$ & 0.646 \\
Carcass Yield (\%) & $42.5 \pm 0.75$ & $42.1 \pm 0.66$ & 0.408 \\
Half-carcass Weight (kg) & $4.52 \pm 0.218$ & $4.54 \pm 0.195$ & 0.959 \\
Carcass Length (cm) & $66.4 \pm 0.806$ & $66.7 \pm 0.721$ & 0.776 \\
Cover fat (1 to 5) & $2.1 \pm 0.191$ & $2.4 \pm 0.171$ & 0.322 \\
Leg (kg) & $1.6 \pm 0.079$ & $1.5 \pm 0.070$ & 0.711 \\
Leg\% & $35.4 \pm 0.8$ & $34.3 \pm 0.7$ & 0.372 \\
Shoulder (kg) & $0.93 \pm 0.04$ & $0.98 \pm 0.04$ & 0.503 \\
Shoulder\% & $20.6 \pm 0.4$ & $21.7 \pm 0.4$ & 0.117 \\
Loin (kg) & $0.27 \pm 0.03$ & $0.41 \pm 0.03$ & 0.022 \\
Loin\% & $6.07 \pm 0.6$ & $8.95 \pm 0.6$ & 0.007 \\
Back (kg) & $0.45 \pm 0.02$ & $0.44 \pm 0,02$ & 0.774 \\
Back\% & $10.0 \pm 0.5$ & $9.7 \pm 0.4$ & 0.655 \\
Rib/belly (kg) & $0.41 \pm 0.02$ & $0.49 \pm 0.02$ & 0.032 \\
Rib/belly\% & $9.09 \pm 0.4$ & $10.8 \pm 0.3$ & 0.006 \\
Neck (kg) & $0.46 \pm 0.03$ & $0.53 \pm 0.02$ & 0.119 \\
Neck\% & $10.2 \pm 0.3$ & $11.6 \pm 0.3$ & 0.105 \\
\hline
\end{tabular}


Tannin from Acacia mearnsii did not affect $(P>0.05)$ carcass yield, carcass length or cover fat (Table 1). For TG values of 42.5, 66.44 and 2.18 were found for these traits, and 42.19, 66.75 and 2.45 for CG, respectively.

The weights and proportions of non-carcass compounds did not differ $(P>0.05)$ between groups, with the exception of skin thickness (Table 2$)$, where TG showed a higher value $(0.26 \mathrm{~mm})$.

Table 2. Least squares means \pm standard error of weights and proportions (on carcass weight basis) of non-carcass components of lambs receiving tannin from Acacia mearnsii (TG) and control group not receiving $\operatorname{tannin}(\mathrm{CG})$

\begin{tabular}{llll}
\hline Variables & TG & CG & $P$ \\
\hline Skin $(\mathrm{kg})$ & $1.61 \pm 0.104$ & $1.61 \pm 0.093$ & 0.986 \\
Skin\% & $17.0 \pm 1.44$ & $17.7 \pm 1.28$ & 0.723 \\
Skin thickness $(\mathrm{mm})$ & $0.26 \pm 0.01$ & $0.15 \pm 0.01$ & 0.003 \\
Thoracic organs $(\mathrm{kg})$ & $0.57 \pm 0.02$ & $0.55 \pm 0.01$ & 0.402 \\
Thoracic organs\% & $6.07 \pm 0.28$ & $6.03 \pm 0.25$ & 0.921 \\
Abdominal organs $(\mathrm{kg})$ & $0.51 \pm 0.01$ & $0.49 \pm 0.01$ & 0.343 \\
Abdominal organs\% & $5.40 \pm 0.13$ & $5.33 \pm 0.12$ & 0.722 \\
Testicles $(\mathrm{kg})$ & $0.21 \pm 0.02$ & $0.28 \pm 0.02$ & 0.089 \\
Testicles\% & $2.22 \pm 0.29$ & $3.04 \pm 0.31$ & 0.075 \\
\hline
\end{tabular}

Tannin treatment did not affect $(P>0.05)$ rib eye area, weights and percentage of muscle, fat or bone of $12^{\text {th }}$ rib. The chemical analysis showed that tannin reduced $(P<0.05)$ EE and increased CP (Table 3).

Table 3. Least squares means \pm standard error of physical and chemical analysis of $12^{\text {th }}$ rib from santa inês lambs receiving tannin from acacia mearnsii (TG) and a control group not receiving tannin (CG)

\begin{tabular}{llll}
\hline Physical analysis & TG & CG & $P$ \\
\hline Weight (g) & $50.56 \pm 4.45$ & $49.20 \pm 3.98$ & 0.823 \\
Muscle (g) & $29.81 \pm 2.88$ & $28.42 \pm 2.58$ & 0.725 \\
Muscle\% & $59.12 \pm 2.0$ & $57.36 \pm 1.79$ & 0.508 \\
Fat (g) & $6.28 \pm 1.26$ & $4.19 \pm 1.12$ & 0.233 \\
Fat\% & $12.42 \pm 2.38$ & $8.52 \pm 2.13$ & 0.165 \\
Bone (g) & $11.87 \pm 1.35$ & $13.67 \pm 1.20$ & 0.334 \\
Bone\% & $23.47 \pm 1.9$ & $27.80 \pm 1.7$ & 0.067 \\
Rib eye area $\left(\mathrm{cm}^{2}\right)$ & $7.75 \pm 0.54$ & $6.92 \pm 0.48$ & 0.273 \\
\hline Chemical analysis & & & \\
\hline Dry Matter $(\%)$ & $30.8 \pm 1.44$ & $32.7 \pm 1.53$ & 0.392 \\
Crude Protein (\%)* & $65.89 \pm 1.35$ & $60.5 \pm 1.21$ & 0.009 \\
Ether Extract (\%)* & $5.76 \pm 1.28$ & $9.37 \pm 1.15$ & 0.050 \\
Ash (\%)* & $22.93 \pm 0.98$ & $22.52 \pm 0.88$ & 0.756 \\
\hline
\end{tabular}

* On dry matter basis.

\section{Discussion}

The mean and standard deviations of the chemical analysis of Andropogon gayanus grass showed the low nutritional quality of feed offered to animals during the experiment. The crude protein level (9.4\%) offered was reflected in low animal performance, assocaited with natural infection by ectoparasites which is inevitable at pasture (Cenci et al., 2007). Nevertheless, this composition is sufficient for maintenance of a low-requirement sheep breed such as the Santa Inês, which is considered more resistant to endoparasites than wool breeds (Bricarello et al., 2005).

The effect of condensed tannins in ruminant diet depends on their level in the diet and the frequency of their use. Tannin concentration above $8 \%$ in the diet can decrease animal performance due to low intake, digestibility and nitrogen absorption, due to the destructive action of the intestine villi and their functions (Robins \& Brooker, 
2005). Animals receiving 4 to $6 \%$ of condensed tannins in total diet demonstrated higher intestinal amino acid absorption (methionine and cysteine), as well as higher milk production and ovulation rate (Aerts et al., 1999).

As well their nutritional effect, CT can have other effects on endoparasites as seen by por Barry and McNabb (1999) who demonstrated that lambs fed on pasture with moderate tannin can reduce infection in two manners. One manner is indirect, where the immune response is improved through better nutrition and supply of essential amino acids as the condensed tannin can compensate for the loss of proteins by intestine caused by parasitism.

Another way would be the direct role of CT on worms. In this experiment the concentration of $3.24 \mathrm{~g}$ condensed tannin and frequency of once a week was pre set to show the direct effect on worms at the expense of nutrition, as described by Cenci et al. (2007), where the TG sheep had a total number of worms of 4,227 against 10,003 in the CG $(P<0.05)$. The species of helminths found in descending order for both groups were: Trichostrongylus colubriformis, Haemonchus contortus, Oesophagostomum columbianum and Cooperia sp.

The CT may act at different stages of the life cycle of endoparasites, mainly by binding proteins/enzymes (Hoste et al., 2012). In the present experiment, the reduction in the number of parasites of sheep receiving CT may have occurred by its action in delaying the exsheathment of the infective larvae (L3) in the rumen (Brunet et al., 2008b), as well as hindering the larvae penetration in the mucosa of the digestive tract (Brunet et al., 2008a). It may also have an effect on the adult worm, which is more resistant than CT larvae (Iqbal et al., 2007).

In both groups there was a predominance of T. colubriformis, which are located in the small intestine and are responsible for the destruction of the mucosa, characterized by atrophy and erosion of the duodenal villous epithelium (Cardia et al., 2011), which is the main site of absorption of nutrients. Although to a lesser extent, the $H$. contortus that colonizes the abomasum, appears to be more pathogenic than $T$. colubriformis, because its hematophagous behavior is severe in sheep.

The low infection in TG group was decisive for the better carcass traits, especially $12^{\text {th }}$ rib, with a lower proportion of bone, higher protein content and lower fat content compared to CG. According to Silva and Pires (2000), the rib is the cut that best represents the proportion of bones, muscle and fat in the carcass.

There is an intimate relationship between parasite load and animal performance, the higher performance seen in the lowest infection group (Louvandini et al., 2003). In parasitized sheep, increased nutritional requirements in general (energy, protein, minerals and vitamins) occur. In particular, the maintenance metabolizable protein, which can increase from 20 to $25 \%$ in growing lambs, is used to repair tissue damage caused by infection (Kyriazakis \& Houdijk, 2006). In this sense, not only the higher level of protein in the $12^{\text {th }}$ rib, but also the thicker skin found in TG sheep, confirm the increased availability of amino acids for these animals, compared to CG. As well as meat, in the hair sheep production system, the skin of these animals is of great commercial interest, which produces leather products with high added value.

Fat deposition in the $12^{\text {th }}$ rib is expected to have similar behavior to protein. However, the fat content was lower for TG sheep. For human consumption that this characteristic is desirable (more protein and less fat). The reduced fat in the carcass of sheep was also reported by Purchas and Keogh (1984) working with lambs on pasture fed with tanniniferous Penduculatus L. forage and Terril et al. (1992) when they offered Coronarium L. and Hedysarum coronarium can be explained by the inactivation of proteins in the gut wall caused by condensed tannin. Another explanation suggested by Barry et al. (1986) and Mangan (1988) would be a positive correlation between the levels of CT in the diet and growth hormone in lambs, which would increase nitrogen retention and lipid turnover.

In the present experiment, sheep were fed exclusively tropical forage (Andropogon gayanus) with low EE (2.6\%), and high body fat was derived from the unfolding of dietary energy coming from the short-chain fatty acids (SCFA) absorbed from the rumen, and the lower proportion of fatty acids absorbed in the intestine. According to Doyle et al. (2011) ruminal fermentation of infected sheep may be altered in response to infection and its resistance to it, such as increase in fluid outflow and turnover rate and a decrease in propionic acid concentration. These aspects should be better monitored in future studies involving CT, grazing and endoparasites, due to the complexity of the factors involved.

\section{Conclusion}

The control of endoparasites in sheep at pasture used condensed tannin from the Acacia mearnsii increases protein and decrease fat in the $12^{\text {th }}$ rib.

\section{Acknowledgements}

The authors would like to thank Nutron for mineral salt mixture as well as FINATEC, CNPq and FAPDF for 
financial support.

\section{References}

Aerts, R. J., Barry, T. N., \& McNabb, W. C. (1999). Polyphenols and agriculture: beneficial effects of proanthocyanidins in forages. Agriculture Ecosystems and Environment, 75, 1-12. http://dx.doi.org/10.1016/S0167-8809(99)00062-6

AOAC (Association of Official Analytical Chemists). (2005). Official Methods of Analysis of the Official Analytical Chemists (18th ed.), In W. Horwitz (Eds.). AOAC, Washington DC.

Barry, T. N., Allsop, T., \& Kedekopp, C. (1986). The role of condensed tannins in the nutritional value of Lotuc pendiculatus for sheep. 5. Effects on the endocrine system and on adipose tissue metabolism. The British Journal of Nutrition, 56, 607-614. http://dx.doi.org/10.1079/BJN19840055

Barry, T. N., \& McNABB, W. C. (1999). The implications of condensed tannins on the nutritive value of temperate forages fed to ruminants. British Journal of Nutrition, 81, $263-272$. http://dx.doi.org/10.1017/S0007114599000501

Bricarello, P. A., Amarante, A. F. T., Rocha, R. A., Cabral Filho, S. L., Huntley, J. F., Houdijk, J. G., ... Gennari, S. M. (2005). Influence of dietary protein supply on resistance to experimental infections with Haemonchus contortus in Ile de France and Santa Ines lambs. Veterinary Parasitology, 135, 99-109. http://dx.doi.org/10.1016/j.vetpar.2005.05.068

Brunet, S., Jackson, F., \& Hoste, H. (2008a). Effects of sainfoin (Onobrychis viciifolia) extract and monomers of condensed tannins on the association of abomasal nematode larvae with fundic explants. International Journal for Parasitology, 38, 783-790. http://dx.doi.org/10.1016/j.ijpara.2007.10.018

Brunet, S., Martinez-Ortiz-De-Montellano, C., Torres-Acosta, J. F. J., Sandoval-Castro, C. A., Aguilar-Caballero, A. J., Capetillo-Leal, C. M., \& Hoste, H. (2008b). Effect of the consumption of Lysiloma,latisilliquum on the larval establishment of parasitic nematodes in goats. Veterinary Parasitology, 157, 81-88. http://dx.doi.org/10.1016/j.vetpar.2008.07.013

Cardia, D. F. F., Rocha-Oliveira, R. A., Tsunemi, M. H., \& Amarante, A. F. T. (2011). Immune response and performance of growing Santa Ines lambs to artificial Trichostrongylus colubriformis infections. Veterinary Parasitology, 182, 248-258. http://dx.doi.org/10.1016/j.vetpar.2011.05.017

Cenci, F. B., Louvandini, H., McManus, C. M., Dell’ Porto, A., Costa, D. M., Araújo, S. C., Minho, A. P., \& Abdalla, A. L. (2007). Effects of condensed tannin from Acacia mearnsii on sheep infected naturally gastrintestinal helminthes. Veterinary $\quad$ Parasitology, 132-137. http://dx.doi.org/10.1016/j.vetpar.2006.09.021

Cunha, E. A., Bueno, M. S., Santos, L. E., Roda, D. S., \& Otsuk, I. P. (2001). Desempenho e características de carcaça de cordeiros Suffolk alimentados com diferentes volumosos. Ciência Rural, 31, 671-676. http://dx.doi.org/10.1590/S0103-84782001000400018

Cuthbertson, A., Harrington, G., \& Smith, R. J. (1972). Tissue separation - to assess beef and lamb variation. Proceedings of the British Society of Animal Production, 1, 113-122. dx.doi.org/10.1017/S0308229600000192

DeMello, J. P. F., \& Devendra, C. (1995). Tropical Legumes in Animal Nutrition. CAB International.

Doyle, E. K., Kahna, L. P., \& McClureb, S. J. (2011). Rumen function and digestion of Merino sheep divergently selected for genetic difference in resistance to Haemonchus contortus. Veterinary Parasitology, 179, 130-136. http://dx.doi.org/10.1016/j.vetpar.2011.01.063

Hoste, H., Martinez-Ortiz-De-Montellano, C., Manolaraki, F., Brunet, S., Ojeda-Robertos, N., Fourquaux, I., ... Sandoval-Castro, C. A. (2012). Direct and indirect effects of bioactive tannin-rich tropical and temperate legumes against nematode infections. Veterinary Parasitology, 186, 18-27. http://dx.doi.org/10.1016/j.vetpar.2011.11.042

Iqbal, Z., Sarwar, M., Jabbar, A., Ahmed, S., Nisa, M., Sajid, M. S., ... Yaseen, M. (2007). Direct and indirect anthelmintic effects of condensed tannins in sheep. Veterinary Parasitology, 144, $125-131$. http://dx.doi.org/10.1016/j.vetpar.2006.09.035

Kyriazakis, I., \& Houdijk, J. (2006). Immunonutrition: Nutritional control of parasites. Small Ruminant Research, 62, 79-82. http://dx.doi.org/10.1016/j.smallrumres.2005.07.036 
Louvandini, H., Gennari, S. M., Abdalla, A. L., \& McManus, C. M. (2003). Influence of protein intake on carcass composition of calves infected with Haemonchus placei. Archivos de Zootecnia, 52, 305-314.

Luciano, G., Vasta, V., Monahan, F. J., López-Andrés, P., Biondi, L., Lanza, M., \& Priolo, A. (2011). Antioxidant status, colour stability and myoglobin resistance to oxidation of Longissimus dorsi muscle from lambs fed a $\begin{array}{lllll}\text { tannin-containing } & \text { diet. } & \text { Food } & \text { Chemistry, } & 124,\end{array}$ http://dx.doi.org/10.1016/j.foodchem.2010.07.070

Makkar, H. P. S. (2003). Effects and fate of tannins in ruminant animals, adaptation to tannins, and strategies to overcome detrimental effects of feeding tannin-rich feeds. Small Ruminant Research, 49, 241-256. http://dx.doi.org/10.1016/S0921-4488(03)00142-1

Mangan, J. L. (1988). Nutritional effects of tannins in animal feeds. Nutrition Research Reviews, 1, 209-231.

Miller, S., McDonald, P. M., Brooker, J. D., \& Martin, P. (1995). Feral goat fluid increases nitrogen retention in sheep consuming a mulga (Acacia aneura) diet. Australian Journal of Agricultural Research, 46, 1545-1554. http://dx.doi.org/10.1071/AR9951545

Müller, L. (1987). Normas para avaliação de carcaças e concurso de carcaças de novilhos. (Universidade Federal de Santa Maria: Imprensa Universitária, UFSM).

Osório, J. C. S., Osório, M. T. M., Jardim, P. O., Pimentel, M. A., Pouey, J. L., Cardellino, R. A., ... Esteves, R. (1998). Métodos para avaliação da produção de carne ovina: "In vivo" na carcaça e na carne. Universidade Federal de Pelotas: Editora e Gráfica Universitária, UFPEL.

Priolo, A., Waghorn, G. C., Lanza, M., Biondi, L., \& Pennisi, P. (2000). Polyethylene glycol as a means for reducing the impact of condensed tannins in carob pulp: effects on lamb growth performance and meat quality. Journal of Animal Science, 78, 810-816.

Purchas, R. W., \& Keogh, R. G. (1984). Fatness of lambs grazed on lotus and white clover. New Zealand Society of Animal Production, 44, 219-221.

Rahmann, G., \& Seip, H. (2006). Alternative strategies to prevent and control endoparasite diseases in organic sheep and goat farming systems - a review of current scientific knowledge. In R. Gerold (Ed.), Ressortforschung für den Ökologischen Landbau (Vol. 298, pp. 49-90). Sonderhefte der Landbauforschung Völkenrode.

Robins, C., \& Brooker, J. D. (2005). The effects of Acacia aneura feeding on abomasal and intestinal structure and function in sheep. Animal Feed Science and Technology, 121, 205-215. http://dx.doi.org/10.1016/j.anifeedsci.2005.02.019

Santos, C. L., Pérez, J. R. O., Muniz, J. A., Geraseev, L. C., \& Siqueira, E. R. (2001). Relative Development of the bone, muscular and fat tissues of joints of the carcass of Santa Inês lambs. Brazilian Journal of Animal Science, 30, 487-492. http://dx.doi.org/10.1590/S1516-35982001000200027

Silva, L. F., \& Pires, C. C. (2000). Avaliações quantitativas e predição de proporções de osso, músculo e gordura da carcaça em ovinos. Revista Brasileira de Zootecnia, 29, 1253-1260. http://dx.doi.org/10.1590/S1516-35982000000400040

Van Soest, P. J., Robertson, J. B., \& Lewis, B. A. (1991). Methods for dietary fiber, neutral detergent fiber and nonstarch polysaccharides in relation to animal nutrition. Journal of Dairy Science, 74, 3583-3597. http://dx.doi.org/10.3168/jds.S0022-0302(91)78551-2

Vasta, V., Mele, M., Serra, A., Scerra, M., Luciano, G., Lanza, M., \& Priolo, A. (2009). Metabolic fate of fatty acids involved in ruminal biohydrogenation in sheep fed concentrate or herbage with or without tannins. Journal of Animal Science, 87, 2674-2684.

Walton, J. P., Waghorn, G. C., Plaizier, J. C., Birtles, M., \& McBride, B. W. (2001). Influence of condensed tannins on gut morphology in sheep fed Lotus pedunculatus. Canadian Journal of Animal Science, 81, 605-607.

\section{Copyrights}

Copyright for this article is retained by the author(s), with first publication rights granted to the journal.

This is an open-access article distributed under the terms and conditions of the Creative Commons Attribution license (http://creativecommons.org/licenses/by/3.0/). 